\title{
Yahudi Âlimlerin Gözüyle Matbaanın İcadı ve Matbaada Basılan Metinlerin Hükmü
}

\author{
Yasin Meral*
}

\section{$\ddot{O}_{z}$}

Matbaanın icadı, kitabın tarihinde çok önemli bir dönüm noktasıdır. Matbaa, başta Avrupa'daki Yahudiler olmak üzere Yahudi dünyasında da çok önemli değişimler yaratmıștır. Bu makalede matbaanın icadının Yahudi ilim adamları tarafindan nasıl karşılandığı ele alınacaktır. Bu çerçevede, Yahudi dinî literatüründe matbaanın icadını Yahudilere nispet eden anlatımlar, Yahudilerin matbaaya atfettikleri önem ve kutsal metinlerin matbaa baskılarının ritüellerde kullanımına dair başlıklar irdelenecektir. Makalenin ana konusunu matbaada basılan dinî metinlerin Yahudi dinî hukukuna göre kaşer (caiz) olup olmadığı oluşturmaktadır. Bu tartışmaların incelenmesi sırasında matbaanın icat edildiği asır ve hemen sonraki asırlarda Yahudi âlimler tarafindan konuyla ilgili verilen fetvalar araştırmamızın temel kaynaklarını oluşturmaktadır. Böylelikle okurlar, birinci elden kaynaklarla, o dönemdeki fetvaların içeriği ve Yahudiler arasındaki tartışmanın boyutlarını görmüş olacaktır.

Anahtar Kelimeler: Matbaa, Sefer Tora, Tefilin, Mezuza, Get, Kaşer, baskı, yazı, Yahudi.

\section{The Invention of the Printing through the Eyes of Jewish Scholars and Responsas on the Books Printed in Printing Houses}

\footnotetext{
Abstract

The invention of the printing press is a very important turning point in the history of the book. The printing house has created significant changes in the Jewish world, especially in Europe. In this article, how the invention of the printing press is met by

* Doç. Dr., Ankara Üniversitesi, İlahiyat Fakültesi, Felsefe ve Din Bilimleri Bölümü, Ankara/TÜRKIYE, yasinmeral1979@gmail.com ORCID: 0000-0001-5794-721X DOI:

Makale Gönderim Tarihi:18.09.2019 - Makale Kabul Tarihi: 09.01.2020
} 
Jewish scholars will be discussed. In this context, the issues such as narratives that attribute the invention of the printing to the Jews in the Jewish religious literature, the importance attributed to the printing press by the Jews and ritual use of the books printed in printing houses will be examined. The main subject of the article is whether the religious texts printed in the printing press are ritually kosher according to Jewish religious law. During the examination of these debates, the responsas given by the Jewish scholars on the subject during the centuries when the printing house was invented and the next centuries are the main sources of our research. In this way, readers will have seen, via first-hand sources, the content of responsas in that period and the extent of the debate among the Jews.

Keywords: Printing House, Sefer Tora, Tefillin, Mezuza, Get, Kasher, printing, script, Jew.

\section{Giriş}

Insanlık tarihinin en önemli icatlarından birisi hiç şüphesiz matbaadır. Matbaa öncesi yazı faaliyeti tarihinde iki önemli değişim göze çarpmaktadır. Çok eskilerde yazılar deri ya da parşömenlere yazılır ve rulo/tomar halinde korunurdu. Miladi 1-5. yüzyıllar arasında bu rulo geleneği yerini bugünkü cilt şeklinde olan kodekse bıraktı. Yazım malzemeleri açısından bu önemli bir değişimdi. 11. yüzyıldan sonra da Araplar eliyle kâğıdın Avrupa'ya taşınması, parşömenin terk edilip yerine kâğıdın kullanılmasına yol açtı. ${ }^{1}$ Yazı malzemeleri açısından ikinci büyük değişim de bu şekilde gerçekleşti. Matbaanın icadı ise başta Avrupa tarihi olmak üzere bütün bir insanlık tarihinde çok ciddi değişimleri beraberinde getirdi. Matbaa olarak isimlendirilebilecek baskı türleri çok eski dönemlere gitmekle birlikte, harfleri değiştirilebilir matbaa Almanya’nın Mainz şehrinde Johann Gutenberg (ö. 1468) tarafindan kuruldu. Gutenberg, metal seyyar harflerin dökümünü yaparak basım işine pratiklik kazandırdı. İlk olarak 1440’ta matbaacılık faaliyetlerine başlayan Gutenberg, baskı faaliyetlerini sürekli iyileştirerek daha kaliteli hale getirdi. Onun ilk bastığı kitap, 1452-1455 yılları arasında yüz seksen kopya olarak hazırladığı Kitab-1 Mukaddes'tir. ${ }^{2}$

Matbaacılık faaliyetlerinin ilk yüzyılında en çok dikkat çeken hususlardan biri de Yahudilerle Hıristiyanların İbranice kitap basımında yaptıkları işbirliğidir.

1 Rudolf Hirsch, Printing, Selling and Reading 1450-1550, Otto Harrassowitz 1967, ss. 2-3.

2 Bkz. Elizabeth Mongan \& Edwin Wolf, The First Printers and Their Books, The Free Library of Philadelphia, Philadelphia 1940, ss. 7-8. 
İtalya'nın bazı bölgeleri başta olmak üzere, Yahudilerin matbaa işletmelerinin yasak olduğu yerlerde Hiristiyan matbaacılar, Yahudi editörler istihdam ederek İbranice kitap basmışlardır. El yazmasından matbaaya geçişte ortaya çıkan bu husus özel bir durumdur. Zira el yazmaları döneminde Yahudi-Hıristiyan işbirliği son derece sınılıydı. ${ }^{3}$ Matbaanın icadını müteakip Yahudiler ve Hıristiyanlar işbirliği yapmak durumunda kalmışlardır. Yahudilere matbaa işletme izninin verilmediği yerlerde Yahudi âlimler, Hıristiyanlara ait matbaalarda İbranice kitap basımında editör olarak çalı̧mışlardır. Nitekim Hıristiyanlar tarafından işletilen matbaalarda basılan Tevrat ve diğer Yahudi metinlerinin kutsal olup olmadığına dair tartışmalar da matbaaların Yahudi olmayanlar tarafindan işletilmesi bağlamında gündeme gelmiştir.

Matbaanın ortaya çıkışıyla aynı zamanda yeni bir okuyucu sınıfı oluşmuştur. El yazmaları döneminde gerek ilmî seviye gerekse maddi imkânlar açısından belli bir grubun tekelinde olan ilmi faaliyetler, ortalama bir eğitimi olan insanlar için de bir imkân oluşturmuştur. Bu noktada gerek kitapların el yazmalarına göre daha ucuz oluşu gerekse çok farklı ilim dallarında basılan kitaplar, ilmi seviyenin toplum katmanlarında yayılmasına hizmet etmiştir. ${ }^{4}$ Böylece zaman içerisinde roman, şiir, tarih, coğrafya, mantık vs. gibi farklı dallarda da eserler, okuyucuların talepleri doğrultusunda basılmaya başlanmıştır. Fakat ilk başlarda öncelikle ihtiyaç olan alanlarda ve pratik sebeplerden ötürü yazması olan metinlerin basımlarına öncelik verilmiştir. Bunlar arasında, tefsirleriyle birlikte Tevrat basımları ilk sırada yer almaktadır. ${ }^{5}$

\section{Matbaaya Yahudi Kökeni Bulma Arayışları}

Matbaanın icadı Yahudiler tarafindan çok olumlu karşılanmıştır. Bazı Yahudi âlimler matbaa kadar faydalı bir icadın kredisinin Yahudilere yazılması gerektiğini düşünerek matbaanın icadıyla ilgili ilginç iddialar ortaya atmışlardır. Bu iddialarda matbaanın Gutenberg tarafindan icat edildiğine dair genel geçer kabulün aksine eski çağlarda Yahudiler tarafından icat edildiği ve kullanıldığı öne sürülmektedir.

3 Adam Shear \& Joseph R. Hacker, "Book History and the Hebrew Book in Italy", The Hebrew Book in Early Modern Italy, ed. Joseph R. Hacker ve Adam Shear, University of Pennyslvania Press, Philadelphia 2011, s. 6.

4 Brian Richardson, "The Debates on Printing in Renaissance Italy", La Bibliofilia 100:2/3 (1998), ss. 138-142; David B. Ruderman, Jewish Thought and Scientific Discovery in Early Modern Europe, Yale University Press, New Haven 1995, s. 52.

5 Mehlman, Genuzot Sefarim, The Jewish National and University Library Press, Kudüs 1976, s. 3. 
Bunlar arasında matbaanın Eyüp peygamber zamanında kullanıldığı, Hz. Musa, Hz. Davud ve Hz. Süleyman'ın matbaadan haberdar oldukları, MS. 70 yılında Mabed'in yıkılmasından önce Ben Kamtsar adlı bir Yahudi kâtibin, arkadaşlarına baskı faaliyetini öğretmediği için kınandığı yer almaktadır. Ayrıca Arap Yarımadası'nda yaşadığı iddia edilen Benyamin kabilesinin I. Mabed'in yıkılmasından (MÖ. 586) önce matbaayı kullandıkları da iddialar arasındadır. ${ }^{6}$

Matbaanın Eyüp peygamber tarafindan icat edildiğine dair iddia, $1607^{7}$ yllında Mantua'da basılan Şiltey ha-Giborim isimli eserde Avraham Portaleone (ö. 1612) isimli Yahudi bir doktor tarafından dile getirilmiştir. O, bu iddiasını Eyüp Kitabı'ndaki şu cümleye dayandırmaktadır: "Keşke şimdi sözlerim yazılsa, kitaba kaydolunsayd (yuhaku), demir kalemle, kurşunla sonsuza dek kalsın diye kayaya kazılsaydı!"’8 Müellif buradaki yazma filini kalemle yazmaya, demir kalem ve kurşunla kazıma ifadesini de matbaadaki baskıya delil olarak göstermektedir. Kaydolma kelimesiyle çevrilen yuhaku ifadesi, İbranicede hakika (oymacılık-kakmacılık) ile ifade edilmektedir. Metinde ise bu taş ya da tahtaya değil, kitaba yapılan bir fiil olarak kullanılmaktadır. Bu da matbaada yapılan baskıları andırmaktadır. Böylece bu detayları ifade eden birisi olarak Eyüp peygamberin matbaada yapılan faaliyetin ilk örneklerinden birini sunduğu ve bundan haberdar olduğu ifade edilmektedir. Portaleone, ayrıca matbaanın yeni icat edildiğini söyleyenleri de eleştirmektedir. ${ }^{9}$

Yahudi dinî literatüründe matbaaya köken bulma gayreti Portaleone ile sınırlı değildir. Eyüp peygamberin dışında Hz. Musa ve Hz. Süleyman da matbaanın mucitleri olarak kaynaklarda zikredilmektedir. Hz. Musa'nın matbaayla olan ilişkisi iki açıdan değerlendirilmektedir. Bunlardan ilki, Eyüp peygamberin matbaadan haberdar olması durumunda Eyüp Kitabı'nın yazarı olduğu düşünülen Hz. Musa'nın da doğal olarak matbaanın bilgisine sahip olduğudur. Bir diğer husus da Hz. Musa'nın bütün ilim dallarında kabiliyeti olduğuna dair geleneksel inanıştır. Hz. Süleyman da Yahudi geleneğinde hikmet/bilgelik konusunda insanların en üstünü kabul edildiği için onun da matbaadan haberdar olduğu düşünülmektedir. Yehezkiel Katzenellenbogen (ö. 1749), Knesset Yehezkiel isimli fetvalardan oluşan

6 Michael Pollak, "The Invention of Printing in Hebrew Lore", Gutenberg-fahrbuch (1977), ss. 22-28; Adam Shear \& Joseph R. Hacker, a.g.m., s. 4.

7 Eserin tarihi yaygın bir yanlışlıkla 1612 olarak verilmektedir.

8 Eyüp Kitabı, 19:23-24.

9 Avraham Portaleone, Şiltey ha-Giborim, Mantua 1607, ss. 183b-184a. İnceleme için bkz. Pollak, a.g.m., s. 25; Berliner, "Haşpaat Sifrey ha-Defus ha-Rişonim al Tarbut ha-Yehudim", Ktavim Nivharim, Mosad Rav Kook, Jerusalem 1945, c. 2, s. 122. 
eserinde matbaa faaliyetinin Hz. Musa ve Hz. Süleyman tarafindan bilindiğini iddia etmektedir. Katzenellenbogen, Tanrı'yla yüz yüze görüşen Hz. Musa ve bütün insanlardan daha bilge olarak nitelenen Hz. Süleyman'mn matbaadan habersiz olmaları ve bu faaliyetin Yahudi olmayan birisi tarafindan bulunmasının normal olmadığını ifade etmektedir. Ona göre Hz. Musa ve Hz. Süleyman, bu bilgiye sahiptiler, fakat onların zamanında baskıcılık faaliyetleriyle bilgiyi yayma ihtiyacı yoktu. Bilgiler şifahi olarak aktarılıyordu ve yazılmak istendiğinde de Sefer Tora örneğinde olduğu gibi bir deri üzerine yazılmaktaydı. ${ }^{10}$

Matbaada basılan kitaplarda tashihçi olarak çalışan Seligmann ben Moses Simon Ulma, Şabtay ben Akiva Horovitz'e (ö. 1619) ait 1612 tarihli Şefa Tel isimli eserin kolofonunda ${ }^{11}$ matbaanın basit bir icat olmadığını, çok değerli kabiliyetleri ve hikmetleri insanlığa sunduğunu nakletmektedir. Mezmurlar'da yer alan "Rab halkları kaydederken, 'Bu da Siyon'da doğmuş' diye yazacak"12 ifadelerini matbaayla ilişkilendiren Ulma, Yahudi olmayan milletler arasında ortaya çıkan buluşların ve bilgeliklerin de Tanrı tarafından, diğer faydalı buluşlarda olduğu gibi, Siyon'da yani Kudüs'te ortaya çıkmış olarak kabul edileceğini belirtmektedir. Ulma, bir H1ristiyan âlimin kendisine matbaanın Hz. Süleyman döneminde mevcut olduğunu söylediğini nakletmektedir. ${ }^{13}$ Bir başka Yahudi âlim Zvi Hirsch Chajes (ö. 1855) matbaanın icadı konusunda Ulma’yı eleştirerek bu şekilde bir değerlendirmede bulunmanın sağlıksız olduğunu ifade etmektedir. ${ }^{14}$

Her ne kadar Chajes matbaanın kökeniyle ilgili iddianın sağlıksız olduğunu söyleyip bu tür bir ilişkilendirmeyi mantıklı bulmasa da kendisi de matbaanın kökenini miladi birinci yüzylla götürmektedir. Mişna’da Ben Kamtsar isimli bir Tevrat kâtibinin durumu anlatılarak "Ben Kamtsar, yazma işini öğretmeyi istemedi (Ben Kamtsar lo ratsa le-lamed al maase ha-ktav)" 15 ifadelerine yer verilmektedir. Talmud'da Ben Kamtsar'ın bildiği bu özel yazı tekniği, eline dört tüy kalem alıp dört parmağıyla tutup dört harfli bir kelimeyi tek dokunuşta yazması olarak açıklanmaktadır.

10 Yehezkiel Katzenellenbogen, Knesset Yehezkiel, Hotsaat Yisrael Zeev, Sudilkov 1732, s. 29b. Ayrica bkz. Pollak, a.g.m., s. 25.

11 Kitabın editörü, basım yeri, basım tarihi, basıldığı matbaa gibi basım bilgilerinin yer aldığı sayfa için kullanılmaktadır. Erken dönem matbaa baskısı kitaplarda kolofonlar kitabın sonunda yer alırdi.

12 Mezmurlar, 87:6.

13 Şabtay ben Akiva Horovitz, Şefa Tel, Hanau 1612, kolofon.

14 Zvi Hirsch Chajes, Şeelot u-Teşuvot, Zolkiew 1850, s. 13b.

15 Mişna, Yoma, 3:11. 
Hahamlar ve diğer kâtipler bu işi nasıl yapabildiğini kendilerine de öğretmesini istediklerinde o bunu reddetmiştir. Bu sebeple de kendisine beddua edilmiştir. ${ }^{16}$ Chajes, Yahudi hahamların görüşlerine dayanarak Ben Kamtsar'ın tek seferde yazdığı bu dört harfli kelimenin Y-h-v-h harflerinden oluşan Yahve ismi olduğunu nakletmektedir. Dönemin hahamlarının bunu öğretmesine yönelik talepleri dikkate alındığında tek seferde bir kelimeyi yazmanın harfleri tek tek yazmaktan daha kıymetli bir iş olduğu sonucuna varan Chajes, Ben Kamtsar'ın yaptığının matbaacılık faaliyeti olduğunu öne sürmektedir. Matbaacıların bir çok harfe mürekkep sürerek aynı anda kâğıt üzerine bir çok kelimeyi tek seferde basmalarının Ben Kamtsar'ın yaptığı şeyle aynı şey olduğunu dile getiren Chajes, bu sebeple matbaa faaliyeti olarak bilinen bu icadın II. Mabed döneminde (MÖ. 515-MS. 70) Yahudi âlimlerce bilindiğini belirtmektedir (biymey Mikdaş be-Beyt Şeni haya noda'le-hahmey Tisrael hamtsaa zo). ${ }^{17}$

Bu örneklerde görüldüğ̈ü üzere Yahudi âlimlerin matbaaya Yahudi tarihinden bir köken bulma gayreti bu icadın çok değerli ve kutsal bir yenilik olarak görülmesiyle doğrudan ilgilidir. Bu kadar faydalı bir yeniliğin bir Yahudi'ye nispet edilmesi Yahudilerin konumunu da yüceltecektir. Bu bilgiler, Yahudi âlimler arasında matbaayı şeytanlaştırma yönünde herhangi bir tutumun olmadığını göstermesi açısından da önem arz etmektedir.

\section{Yahudi Matbaacılığı ve Matbaaya Atfedilen Önem}

Matbaanın icadını takip eden yıllarda Yahudiler matbaayla doğrudan ilgilenmeye başlamışlardır. İlk İbranice eserler, 1469-1472 yılları arasında Roma'da basılmıştır. ${ }^{18}$ Basılan ilk kitaplar; David Kimhi’nin Sefer ha-Şoraşim adlı İbranice sözlüğü, Tevrat tefsiri, İbn Meymun'un Delâletü'l-Hâirin adlı eserinin İbranice çevirisi, Natanel ben Yehiel'in Sefer ha-Aruh isimli İbranice sözlüğü ve Şlomo ibn Adret’in fetvaları olarak karşımıza çıkmaktadır. Bu eserlerde tarih kaydı bulunmamaktadır. Baskı tarihi belli olan ilk İbranice kitaplar ise Rabbi Şlomo Yitshaki’nin (Raşi, ö. 1105) Tevrat tefsiri ve Ya'kov ben Aşer’in (ö. 1340) Arbaa Turim adlı eseridir. Bu

18 Simon Eliot, Jonathan Rose (ed.), A Companion to the History of the Book, Wiley-Blacwell Publishing, Hong Kong 2009, ss. 156-157; Manule Jose Pedrasa Gracia, "Minor Printing Offices in Fifteenth and Sixteenth Centuries", Print Culture and Peripheries in Early Modern Europe, ed. Benito Rial Costas, Brill, Leiden 2013, s. 311. 
eserler, 1475 yılında İtalya'nın Reggio Calabria şehrinde basılmıştır. ${ }^{19}$ Matbaada kitap basım işinin 1452'den sonra başladığını varsaydığımızda, yaklaşık yirmi yıl içerisinde Yahudilerin de matbaacılık faaliyetlerine başladığı görülmektedir.

Yahudi matbaacılık tarihi incelendiğinde İtalya'nın merkezî bir konumda olduğu görülmektedir. Nitekim matbaanın icadını müteakiben ilk Yahudi matbaaları İtalya'da kurulmuştur. İtalya'nın ardından 1480'li yıllarda İspanya'da, 1490'lı yıllarda da Portekiz'de Yahudi matbaaları çalışmaya başlamıştır. Osmanlı topraklarında da ilk matbaa yine İspanya'dan sürülen Yahudiler tarafindan 1493 yılında kurulmuştur. Matbaaların ilk dönemlerinde gerek harf dökümlerinde gerekse baskı kalitelerinde ciddi sorunlar yaşanmıştır. Bu sebeple matbaacılığın emekleme dönemi olarak isimlendirilen bu dönemde (1450-1500 yllları arasında) basılan eserlere "beşik" anlamına gelen incunabula adı verilmektedir. 1470-1500 yılları arasında incunabula olarak isimlendirilebilecek yüz elli civarında İbranice eser mevcuttur. ${ }^{20}$ Yüz elli farklı kitaptan toplam iki bin civarında kopya günümüze ulaşmıştır. İstanbul'da İspanya'dan sürülen Yahudiler tarafindan basllan 1493 tarihli Arbaa Turim adlı eser, Osmanlı topraklarında ve İslam dünyasında basılan tek incunabula eserdir. ${ }^{21}$ İbranice incunabula eserlerin (1470-1500) ortalama baskı adedi, üç yüzdört yüz civarındadır. ${ }^{22}$

Matbaanın icadı Yahudi çevrelerinde büyük sevinçle karşılanmışır. Sadece el yazmaları olarak bulunan sınırı sayıda kitabın kaybolma, yanma, suda kalma gibi sebeplere kullanılamaz hale gelmesi durumlarına karşı matbaanın icadı büyük bir kolaylık sağlamıştır. Yahudiler açısından konunun daha da önemli yönü, Kilise otoriteleri tarafindan başta Talmud olmak üzere Yahudi dinî metinlerinin yakılmasi $^{23}$ ve toplanması sebebiyle bu metinlerin kaybolma riskinin ortaya çıkmasıdır.

19 David Werner Amram, The Makers of Hebrew Books in Italy, Edvard Stern Publishing, Philadephia 1909, ss. 21-28; Gracia, a.g.m., s. 311.

20 Bu sayıyı 250'ye kadar çıkaranlar da vardır. Bkz. Marvin J. Heller, The Seventeenth Century Hebrew Book, Brill, Leiden 2011, c. 1, s. xiii. Offenberg ise 139 incunabula eserden bahsetmektedir. Bkz. Adri K. Offenberg, Hebrew Incunabula in Public Collections, De Graaf, Nieuwkoop 1990.

21 Silke Schaeper, "Inventory of Hebrew Incunabula", Catalogue of Books Printed in the Fifteenth Century Now in the Bodleian Library, ed. Alan Coates, Oxford University Press, Oxford 2005, s. 2715.

22 Coletta Sirat, Hebrew Manuscripts of the Middle Ages, trans. Nicolas de Lange, The Press Syndicate of the University of Cambridge, Cambridge 2002, s. 12.

23 Polonyalı hahamlardan Rabbi Aharon Gerşon, 1554'te Talmudların yakılmasına dair Papalık fermanının manevi sebebinin 1551 yılında Venedik'te basılan İbn Meymun'un Delâletü'l-Hâirîn isimli eseri olduğunu belirtmektedir. Bkz. Avraham Yaari, Mehkarey Sefer, Mosad Rav Kook, Kudüs 1958, s. 216. 
Ayrıca Yahudilerin yaşadıkları ülkelerden sürülmeleri de Yahudi dinî literatüründeki bazı eserlerin zamanla ortadan kaybolmasina sebep olmuştur. ${ }^{24}$ Fakat matbaa sayesinde çok sayıda baskı yapılarak birçok eve giren ve çok geniş bir coğrafyaya yayılan bu eserlerin kaybolma riski ortadan kalkmaktadır. ${ }^{25}$ Örneğin, Papalık 1553-1554'te Roma'da Talmudları toplatıp yakmaya başlayınca İstanbul'daki Yahudi matbaacılar olan Yaabets kardeşler hemen Talmud basmaya başlamışlardır. ${ }^{26}$

Matbaanın Osmanlı Devleti'nin Müslüman tebaası tarafindan çok geç bir vakitte kullanılmaya başlanmasına sebep olarak genellikle hattatların sayıca fazla olmaları ve iş imkânlarının ortadan kalkması gösterilmektedir. Benzer şekilde Avrupa'da matbaanın ilk olarak ortaya çıktığı dönemden itibaren hattat olarak çalışan Hıristiyan keşişlerin işsizliğe sebep olacağı gerekçesiyle matbaaya karşı çıktıları görülmektedir. Örneğin 1470’li yıllarda Venedik'te kâtip olarak çalışan Dominiken rahip Filippo da Strada, matbaacılığı ukalalık olarak nitelemekte ve bu işle uğraşanları cahil, başıboş, sarhoş ve İtalyan kâtipleri açlıktan öldürmeye zorlayan Alman adamlar olarak ifade etmektedir. Ona göre matbaacilık faaliyetleri cahillerin elindedir. Dönemin matbaalarında çalışan bazı editörler ise matbaacıların açgözlülüklerinden bahsederek metinlerin kalitesizliğinden yakınmaktadırlar. Yine matbaanın, insan ruhu için bir savaş topunun insan bedenine verdiği zarardan daha fazla zarar verdiğini, zira bir topun sadece bedene, matbaanın ise zihinlere ve beyinlere zarar verdiğini belirten ilim adamları da olmuştur. Sayı çokluğunun kaliteyi düşürdüğü, kütüphanelerin lüzumsuz kitaplarla dolduğu gibi eleştiriler de yine Kilise çevresindeki eleştiriler arasındadır. Bununla birlikte gerek Kilise adamları arasından gerekse entelektüeller arasından matbaayla ilgili övgü dolu sözleri işitmek de mümkündür. Bunlar arasında "kutsal sanat", "semadan inen bir zanaat", "yeni ve yazmanın ilahî çeşidi", "çağları aşan görülmemiş mucize", "semavî nimet", "daha iyisi yapılmamış icat" gibi tanımlamalara rastlanmaktadır. ${ }^{27}$

Matbaanın icadı Yahudiler arasında sevinçle karşılanmıştır. Matbaa aleyhinde beyanlara dair çok sınırlı sayıda kayıt mevcuttur. 1490 tarihli Napoli'de basılan Nahmanides'e ait Tevrat tefsirinin sonunda "Matbaanın aleyhine konuşanlar, bunun günahını çekeceklerdir" şeklinde bir ifadeye yer verilmektedir. ${ }^{28} \mathrm{Bu}$ ifade ara-

24 Mehlman, a.g.e., s. 2.

25 Amram, a.g.e., ss. 36-37.

26 Yasin Meral, İstanbul'da Yahudi Matbuat, Divan Kitap, İstanbul 2016, ss. 41-42.

27 Richardson, a.g.m., ss. 136-153.

28 Mehlman, a.g.e., s.2; Daniel Chwolson, Reşit Maase ha-Defus be-Yisrael, Warsaw 1897, s. 6; Amram, 
cllığıyla matbaa aleyhinde konuşanların varlığı dolaylı olarak bilinmektedir. Fakat bu isimler eğer Yahudi ulemasından isimlerse bunu kitaplarında açıkça yazarak en azından kayda geçirmedikleri görülmektedir. Matbaanın icadının Yahudilerce sevinçle karşılandığı basılan İbranice eserlerde de kayıt altına alınmıştır. Avraham Conat, 1476 yllında Mantua'da (İtalya) Ya 'kov ben Aşer'e ait Arbaa Turim'in Oreh Hayim bölümünün kolofonunda matbaayı, herhangi bir mucize olmaksızın birçok kalem kullanarak aynı anda yazı yazmaya (kotev kama kulmusim be-lo maase nisim) benzetmektedir. ${ }^{29}$

İbrani matbaacıllğının ilk dönemlerinden itibaren Yahudi matbaacılar veya müellifler matbaayı öven ve yücelten ifadelere yer vermektedirler. Matbaada basilan İbranice kitaplarda matbaacıllk faaliyetleri genellikle "kutsal bir zanaat (mal'ehet ha-kodeş veya mal'ehet şamayim)" şeklinde tanımlanmaktadır. Bunun temel sebebi de matbaa sayesinde Tanrı'nın emirlerinin hızlı bir şekilde yayılmasıdır. Örneğin, İstanbul'da 1505 yllında basılan Tevrat'n kolofonunda Avraham ibn Yaiş, matbaacılık faaliyetlerini "büyük bir dinî vecibe (mitsva gdola)" olarak tanımlamaktadır. Ona göre matbaa, Tevrat bilgisinin yayllmasına hizmet etmektedir. Abravanel'e ait Roş Amana (İstanbul, 1506) adlı eserin kolofonunda da matbaadan, "kutsal bir zanaat (mal'ehet ha-kodess)" olarak bahsedilmektedir. Yisthak Alfasi'ye ait ha-Hibur ha-Gadol me-ha-Halahot (İstanbul, 1509) adlı eserin Seder Moed bölümünün sonunda, dönemin ünlü Yahudi âlimi Eliyahu ha-Levi, matbaacllı faaliyetlerini "kutsal bir zanaat işi (mal'ehet avodat ha-kodeş)" olarak anlatmaktadır. Hasagot ha-Rambam (İstanbul, 1510) isimli eserde ise "kutsal matbaa zanaatı (mal'ehet ha-kodes mal'ehet ha-defus)" ifadelerine yer verilmektedir. ${ }^{30}$

Tsemah David (1592) isimli tarih kitabının müellifi David Gans (ö. 1613), matbaayı dünyanın yaratılışından kendi zamanına kadar ortaya çıkan yeniliklerin en değerlisi olarak görmektedir. O, matbaanın icadıyla ilgili şu ifadelere yer vermektedir:

"Kitap basımı, Mainz şehrinde Strasbourglu Yohanan Gutenberg tarafin-

a.g.e., ss. 35-36; Berliner, a.g.m., s. 118.

29 Berliner, a.g.m., s. 114; Michael Pollak, a.g.m., s. 24.

30 Meral, a.g.e., s. 63. Kolofonlarda matbaanın kutsal bir iş olduğuyla ilgili örnekler için bkz. Yaari, ha-Defus ha-İri be-Kusta, ss. 60-62, 64, 66, 67-69, 77. Ayrica bkz. Nahum Rakover, Zhut ha-Yotsrim ba-Mekorot ha-Yehudim, Jewish Legal Heritage Society, Kudüs 1991, s. 233; Pavel Sladek, "The Printed Book in the 15th and 16th Century Jewish Culture", s. 13; Berliner, a.g.m., s. 117. Elimizdeki kayıtlara göre matbaa için önce katav ve hakak fiileri kullanıldı, defus kelimesi ise ilk olarak 1477 yılında kullanılmaya başlandı. Kitap basmak fiil olarak ilk defa 1491 yılında kullanıldı. Bkz. Berliner, a.g.m., s. 115; Amram, a.g.e., s. 34; Pollak, a.g.m., s. 24. 
dan icat edildi. Bu, dindar hükümdar Friedrich’in hükümdarlığının birinci yılında, İbrani takvimine göre 5200, Hıristiyan takvimine göre 1440 yılında gerçekleşti. İnsana bilgiyi, insanlığa anlayışı bahşeden yaratıcı mübarektir! Merhametiyle bizi bütün insanlı̆̆n faydasına olacak bunun gibi büyük bir icatla destekleyen yaratıcı mübarektir! Bu yeni icadın bir benzeri yoktur ve Tanrı'nın insanı yarattığı günden bu yana sadece dinî ilimlerde değil, yedi hikmet $^{31}$ de dâhil olmak üzere ortaya çıkan hikmet ve icatlardan bu icat kadar değerli olanı yoktur. Ayrıca günümüzün diğer kabiliyetleri olan sanat, zanaat, sarraflık, yapı işleri, ahşap işlemeciliği, taş işlemeciliği ve diğer ilimler de buna dâhildir. Matbaa sayesinde sınırsız kitap basılarak her gün ve her vakit pek çok yararlı şeyler ve yenilikler gün yüzüne çıkıyor ve ifşa olunuyor. ${ }^{32}$ "

Gans'ın dünya tarihini aktardığı kitabındaki bu ifadeler diğer Yahudi âlimlerden biraz farklılık arz etmektedir. Yahudi âlimler matbaanın önemli bir icat olduğunu ifade ederken bunu genellikle Tevrat bilgisinin yaygınlaşması bağlamında kurgulamakta, Gans ise bunu insanlığın faydasına olacak şeylerin yaygınlaşması ve her türlü ilim dalında ilerleme kaydedileceğine dair ümit çerçevesinde ifade etmektedir.

Hem Avrupa'da hem de Osmanlı Devleti'nde gerek matbaacıların gerekse kitap bastıran Yahudi âlimlerin, matbaacılık faaliyeti için "kutsal zanaat" ifadesini kullandıkları görülmektedir. Yahudi âlimlerin matbaaya önem vermelerinin ve teşvik etmelerinin temelinde Tevrat'ın ve dinî bilgilerin hızlı bir şekilde yayılması yatmaktadır. Bu vesileyle sadece belli âlimler ve zengin insanlar arasında dolaşımda olan bazı kitaplar da hızlı bir şekilde birçok insanın eline ulaşacaktır. Zira matbaadan önce istinsah etme yoluyla kitaplar çoğaltılmaktaydı. Bu iş, hem zaman alan hem de pahalı olduğu için herkes tarafindan tercih edilebilen bir imkân değildi. Fakat matbaayla birlikte hem kitap fiyatları düşmüş hem de matbaacılar bir müstensihin bir ayda yazdığını bir iki günde basmaya başlamışlardır. Matbaayla birlikte oluşan bir diğer imkân da Mikraot Gedolot ${ }^{33}$ gibi bir kitabın içerisinde bir kaç

Birkaç Tevrat tefsirinin Tevrat metniyle birlikte aynı kitap içerisinde basılmasıyla elde edilen özel bir türdür. Bu eserlerde önce Tevrat'ın İbranice orijinal metni sayfanın başında yer alır sonra da sayfa kenarlarında ve altlarında sırasıyla ilgili Tevrat pasajıyla alakalı tefsirler yer alır. Hangi tefsirlerin seçileceği konusu editörlerin takdirine kalmıştır. Bununla birlikte Raşi, İbn Ezra ve Nahmanides gibi çok meşhur müfessirlerin tefsirleri hemen hemen bütün editörler tarafindan tercih edilen tefsirler olmuşlardır. 
kitabın birden basılması vesilesiyle aynı anda pek çok kitaba ulaşım kolaylığıdır. Tanah'ın, Neviim ve Ketuvim bölümündeki kitapların sıralaması da matbaada basılan Tanah nüshaları vesilesiyle bugünkü halini almıştır. Dua kitapları olan sidurların basılması ve cemaatin ezbere bilmediği duaları sinagogda bu kitaplardan takip ederek dualara iştirak etmeye başlaması da yine matbaanın getirdiği avantajlardandır. Matbaacılık faaliyetlerinin ilk dönemlerinde matbaacılar bir kâtibin bir yılda yazdı̆̆ını bir günde bastıklarından bahsetmektedirler. Bir başka matbaacı da bir kâtibin bir nüsha yazdığı bir zaman diliminde aynı kitaptan beş yüz adet bastığını belirtmektedir. ${ }^{34}$ Matbaanın icadı sonrasında müstensihler tarafından kitap yazma işi sadece sinagogda veya bayramlarda okunan litürjik eserlerle sinırlı kalmıştır. Bu çerçevede Tevrat, Ester Kitabı, tefilin ve mezuza metinleri parşömen ve deriye el yazısıyla yazılmaya devam etmiştir. Diğer taraftan zengin Yahudilerin kendi özel kütüphaneleri için el yazması toplamaya/yazdırmaya devam ettikleri de bilinmektedir. ${ }^{35}$

\section{Kutsal Metinlerin Matbaada Basımına Dair Fetvalar}

Her ne kadar Yahudi âlimler matbaayı tam olarak sahiplenseler de kutsal metinlerin matbaada basımı konusunda sorunlar baş göstermiştir. ${ }^{36}$ Kutsal metinlerin matbaada basılmalarıyla ilgili öncelikli sorun, matbaa faaliyetinin tanımıla ilgili ortaya çıkmıştır. Bu sorunun temel nedeni, Tevrat'ın, mezuza ve tefilinde kullanılan metinlerin ve kadına verilen boşama belgesinin (get), Yahudi hukukuna göre yazıyla (katav) oluşturulmuş bir metin olması zorunluluğundan kaynaklanmaktadır. Tevrat'ta yer alan "Eğger bir adam evlendiği kadında yakışısıs bir şey bulur, bundan ötürü ondan hoşlanmaz, boşanma belgesi yazıp ona verir ve onu evinden gönderirse..." ${ }^{\prime 37}$ ifadesi bunun delili olarak gösterilmektedir. Yazılmış olmayan metin, bu objelerin dinî amaçlarla kullanılamayacağı ve geçersiz sayılacağı anlamına gelmektedir. Burada şu soru gündeme gelmektedir: Matbaada yapılan baskı faaliyeti, yazmak fiiliyle ifade edilebilir mi? Bir diğer ifadeyle matbaada basılan bir

34 Berliner, a.g.m., s. 117, 129, 131-135; Richardson, a.g.m., ss. 138-139.

35 Mehlman, a.g.e., s. 2; Adam Shear \& Joseph R. Hacker, "Book History and the Hebrew Book in Italy", The Hebrew Book in Early Modern Italy, ed. Joseph R. Hacker \& Adam Shear, University of Pennyslvania Press, Philadelphia 2011, s. 2; Malachi Beit-Arie, "The Relationship between Early Hebrew Printing and Handwritten Books: Attachment or Detachment", Library Archives, and Information Studies, ed. Dov Schidorsky, Magnes Press, Kudüs 1989, s. 26; Marvin J. Heller, Printing the Talmud: A History of the Earliest Printed Editions of the Talmud, Brill, Leiden 1992, ss. 9-13.

36 Inceleme için bkz. Berliner, a.g.m., ss. 122-126.

37 Tesniye, 24:1. 
metin, yazılmış metin olarak tanımlanabilir mi ${ }^{38}$ Bu endişenin bir sonucu olarak matbaada ilk basılan bazı Tevratların ilk ve son harfleri boş bırakılmış ve bu kısımlar elle yazılarak tamamlanmıştır. Böylece yazı yazmak şartının yerine getirilmesi sağlanmaya çalışılmıştır. ${ }^{39}$

Matbaada basılan Tevrat rulosu ile ilgili başka yazım kuralları da şüphelerin artmasına neden olmuştur. Örneğin, Tevrat'ı yazan kâtip, yazacağı her kelimeden önce o kelimeyi sesli bir şekilde telaffuz etmelidir. Ayrıca Tevrat'ın yazımı sırasında bir başka Tevrat rulosuna bakarak yazılması gerekmektedir. Metni ezberden yazmak geçersiz kabul edilmektedir. Tanrı'nın isminin geçtiği her yerde $l e-s ̧ e m$ keduşat ha-Şem (Tanrı'nın adını kutsamak niyetiyle) şeklinde bir ifade kullanılması ve harflerin sırasıyla ve peş peşe yazılması gerekmektedir. ${ }^{40}$ Tevrat'ın bir kaşer hayvanın derisine yazılması zorunluluğu da mevcuttur. Ayrıca Yahudi olmayan birinin yazdığı Tevrat, dinî ritüellerde kullanılamaz. Bütün bunları bir arada düşündüğümüzde, matbaada tek seferde sayfaları basılan Tevratlarda bu kuralların birçoğuna uyulmadığı görülmektedir. Örneğin, Tanrı'nın isimleri bir sayfada beş defa geçiyorsa matbaacıların bunları sayıp o kadar kutsama yapmaları neredeyse imkânsızdır. Basım tek parçada olduğu için harfler sırasına göre yazılmamaktadır. Kelimelerin tek tek yazımı söz konusu olmadığı için de tek tek telaffuz ederek yazmak söz konusu değildir. Bütün bu eksiklikler matbaada basılan Tevratların ibadetlerde kullanımının mümkün olmadığına dair şüpheleri ortaya çıkarmıştır. ${ }^{41}$

Matbaayla ilgili bu soruna verilecek cevap ilgili metnin kutsal sayılıp sayılmayacağını, bir diğer ifadeyle dinen geçerli olup olmayacağını da ortaya çıkarmaktadır. Matbaayla ilgili bir diğer husus da eskiyen, yıpranan ve yırtılan kitapların yakılması veya gömülmesi sorununun ortaya çıkmasıdır. Bununla ilintili olabilecek bir diğer sorun da matbaada baskı hataları sonucunda ortaya çıkan müsveddelere nasıl muamele edileceğiyle ilgilidir. Zira bu tür metinler, içinde özellikle Tanrı'nın isimlerini barındırması sebebiyle ya gömülmelidirler ya da geniza adı verilen yer-

38 Yitshak Zeev Kahana, Mehkarim be-Sifrut ha-Teşuvot, Mosad Rav Kook, Kudüs 1973, ss. 272-274; Solomon B. Freehof, The Responsa Literature, Varda Books, Illinois 2011, s. 230.

39 Berliner, a.g.m., s. 119.

40 Örneğin, Avraham Gumbiner (ö. 1683) tefilin ve mezuzalarda harf harf yazma şartı olduğu için matbaada basılan tefilin ve mezuza metinlerinin dinen geçerli olmadığını belirtmektedir. Bkz. Avraham Gumbiner, Magen Avraham (Oreh Hayim), fetva no: 32, seif 57.

41 Benzer sorunlar serigrafi baskısıyla oluşturulan Tevratlar için de geçerlidir. Tartışmalar için bkz. J. David Bleich, "Survey of Recent Halakhic Periodical Literature: Silk Screened Torah Scrolls", Tradition: A Fournal of Orthodox Fewish Thought 37:1 (2003), ss. 79-92. 
lerde saklanmalıdırlar. Yahudi âlimlerden bazıları matbaada basılan ve daha sonra kullanılmayacak hale gelen malzemelerin paketlenerek gömülmesini tavsiye ederken bazıları da paketlenmelerine (çanak-çömlek gibi şeylere konulmalarına) gerek olmadığını belirtmektedirler. ${ }^{42}$ Baskı hataları sonucu yüzlerce müsvedde kâğıt ortaya çıkınca bunların yakılması gerektiğini ve ayak altında bu tür metinlerin dolaşmasının saygisızlık olduğunu ifade eden Yahudi âlimler çıkmıştır. Bunun yanında müsvedde bile olsa dinî metinlerin yakılmasının uygun olmadığını ve onları gömmek gerektiğini ifade eden âlimlere de rastlanmaktadır. ${ }^{43}$

\section{a. Matbaa Baskısının Dinen Geçersiz Olduğunu Savunanlar}

Matbaada basılan Tevratların dinen geçerli olup olmadığıyla ilgili daha matbaanın icadıyla birlikte tartışmalar da başlamıştır. Elimize gelen kayıtlar ise matbaadan yaklaşık bir asır sonrasına ait fetvalarla başlamaktadır. Örneğin Moşe Provençal (ö. 1576), 1560 ylında Purim Bayramı'ndan beş gün önce kendisine sorulan bir soru vesilesiyle matbaada basılan eserlerle ilgili değerlendirmede bulunmaktadır. Bu soru Riva di Trento'dan haham ve matbaacı Yosef Ottolenghi'nin Purim Bayramı'nda okunmak üzere on altı adet Ester parşömeni basmasıyla ilgilidir. ${ }^{44}$ Soruyu soran kişi, Ottolenghi'nin, insanları bu parşömenlerden okumaya zorlamadığını fakat bayramda ibadet maksadıyla matbaa baskısı bu metinlerden okumanın da dinen geçerli olduğunu düşündüğünü aktarmaktadır. Bu kişi, Ottolenghi'nin bu iddiasına delil olarak Mişna, Şabat 17:1'den delil getirdiğini nakletmektedir. Mişna'daki rivayete göre Şabat günü üç harfi aynı anda yazan kişi, Şabat gününde yazı yazmama kuralını çiğnemiş sayılmaktadır. Ottolenghi, bu rivayetin harfleri aynı anda basmanın yazı kelimesiyle ifade edilen ameliye olarak tanımlanabileceğini gösterdiğini iddia etmektedir. Soruyu soran kişi bu tür bir çıkarımın aklına yatmadığını ve insanların Ottolenghi’nin bu sözleriyle hataya düşeceklerini belirtmekte ve Provençal'dan bu konuda kendisini aydınlatmasını istemektedir. ${ }^{45}$

42 Louis Jacobs, A Tree of Life Diversity, Flexibility, and Creativity in Fewish Law, The Littman Library of Jewish Civilization, Oregon 2007, s. 153; Przybilski, "Jewish Concepts of Holiness of Script in the Age of Printing: The Case of Genizah", The Aura of the Word in the Early Age of Print, ed. Jessica Biskirk-Samuel Mareel, Routledge Publishing, Oxon 2016, ss. 105-106.

43 Przybilski, a.g.m., s. 106.

44 Gerek Tevrat rulosu gerek diğger parşömene basılmak zorunda olan metinler de matbaada basılabilir. Bilindiği üzere rulo şeklindeki Tevratlar altmış iki adet parşömenin ayrı ayrı yazılmasından sonra birbirlerine iğneyle dikilip birleştirilmesiyle tek parça haline getirilmektedir.

45 Moşe Provençal, Şeelot u-Teşuvot, ed. Avraham Yosef Yanay, Mahon Or ha-Mizrah, Kudüs 1989, c. 1, fetva no: 73 . 
Provençal, bu soruya cevap sadedinde matbaa baskılarının dinen geçersiz sayılıp sayılmamasının sebebinin bütün metni aynı anda basması olmadığını belirtmektedir. Bu sebeple de Ottolenghi’nin delil olarak gösterdiği rivayetin gereksiz ve ilgisiz olduğunu düşünmektedir. Ona göre satır sıralamalarının olmaması da o baskının dinen geçersiz olmasını gerektirmez. Baskı yapılırken her halükarda mürekkebin kâğıda ya da parşömene geçtiğini belirterek bu tür bir yöntemin de metni dinen geçersiz hale getirmeyeceğini ifade etmektedir. Onun matbaada basılan bir metnin dinen geçersiz olmasına yönelik iddiası, matbaada kullanılan teknik ya da malzemelerle ilgili değildir. Provençal, matbaada çalışan ve baskıyı yapan çalışanların çoğunun hatta tamamının Yahudi olmayan kişilerden oluştuğunu, Yahudi olmayan birisi tarafindan yazılan bir metnin de dinen geçersiz olduğunu belirtmektedir. ${ }^{46}$ Provençal'a göre, matbaacının Yahudi olması durumunda da matbaadaki baskı faaliyetinin yazı yazmak fiiliyle ifade edilebilmesi için kâğıt, parşömen ya da deri üzerine mürekkeplenerek basılan tabakadaki metal harflerin nasıl oluşturulduğu önemlidir. O, burada teknik bir ayrıma giderek önemli olanın harflerin baskısının yapılması olduğunu söylemektedir. Ĕger matbaada harfler oyularak bir tabaka oluşturulmuşsa o zaman bu oymacılık-kakmacılık işine girer ve harfler etkisiz durumda olduğu için harflere mürekkep sürülmeden tabakaya mürekkep sürülerek baskı yapılması anlamına gelir ki bu yazı olmaz. Eğer harflerin kenarları oyulup harfler öne çıkarılır ve mürekkep harflere sürülürse o zaman bu yazı ameliyesi yerine geçer ve bu şekilde basılan metinlerden okumak dinî vecibenin yerine getirilmesini sağlar. Ayrıca ona göre, metnin üzerine basıldı̆̆ı malzemenin deri olması gereklidir, zira kâğıt üzerine basılan metin dinen geçerli bir metin değildir. ${ }^{47}$

Konuyla ilgili bir başka kayıt da Yair Hayim Baharah'a (ö. 1702) aittir. O, Havot Yair isimli eserinde matbaada basılan Tevratlarda kutsallık olup olmamasının Tevratların matbaada basılmasıyla ilgili olmadığını iddia etmektedir. Ona göre konu, baskıyı yapanın Yahudi olup olmamasıyla ilgilidir. Bu sebeple Yahudi olmayan birisi tarafindan basılan Tevratlarda herhangi bir kutsallık söz konusu değildir. Yahudilerin ise özel bir niyet ve amaca yönelik saygı ve ihtiramla bu işi yaptıklarında yazılan ya da basılan Sefer Tora, mezuza ve tefilinlerde kutsallık olduğu söylenebilir. Ona göre bir Yahudi tarafindan hazırlanan ve özel bir amaca yönelik olan faaliyetler, o metne kutsallığını vermektedir. Baharah, matbaada basılan boşanma bel-

46 Provençal, a.g.e., fetva no: 73; Vivian B. Mann \& Daniel D. Chazin, "Printing, Patronage and Prayer: Art Historical Issues in Three Responsa", Images: A Journal of Jewish Art and Visual Culture 1 (2007), ss. 92-94.

47 Provençal, a.g.e., fetva no: 73; Mann \& Chazin, a.g.m., ss. 92-94. 
gesinin dinen geçerli olduğunu, fakat Sefer Tora, tefilin ve mezuzanın geçerli olmadığın belirtmektedir. ${ }^{48}$ Baharah bir başka yerde de matbaalarda basılan Tevratlara ve kutsal yazılara saygisızlık yapılmaması ve bu metinlere kutsal olarak muamele edilmesi gerektiği konusunda uyarıda bulunmaktadır. ${ }^{49}$ Bu noktada o, metnin litürjide kullanılması ile kutsal olması arasında bir ayrım yapmaktadır. Bir diğer ifadeyle her ne kadar litürjide kullanımları uygun olmasa da bu durum, matbaada basılan dinî metinlerin kutsallıklarının olmadığı anlamına gelmemektedir. Somut bir örnekle ifade edecek olursak; matbaada parşömene basılip rulo haline getirilen bir Tevrat, kutsal olmakla birlikte, Şabat günlerinde sinagogda Tevrat okuma ritüelinde metin olarak kullanılamaz. Bu çerçevede litürji için uygun olmayış, daha çok teknik şartları taşımamasından kaynaklanan özel bir durumdur. Yoksa matbaada basılan Tevrat'in içeriğiyle elde yazılan Tevrat'nn içeriği arasında herhangi bir fark yoktur.

Bir başka Yahudi âlim Yona ben Eliyahu Landsofer (ö. 1712), Bney Yona adlı eserinde matbaada basılan Tevrat, mezuza ve tefilinin dinen geçerli (kaşer) olmadığını savunmaktadır. Tevrat, mezuza ve tefilin için yazmak (katav) filinin kullanıldığını belirten Landsofer, matbaa faaliyetindeki eylemin "baskı" olduğunu dolayısıyla "yazı" olarak nitelenemeyeceğini belirtmektedir. Kendisinden önce bazı Yahudi âlimlerin matbaa baskısı eserlerin dinî ritüellerde kullanımıyla ilgili farklı fetvalar verdiklerini aktaran Landsofer, kendi kanaatinin olumsuz yönde kanaat bildirenler istikametinde olduğunu ifade etmektedir..$^{50}$

Matbaada basılan kitapların dinî statüsüyle ilgili bir diğer fetva da Rabbi Eliezer Fleckles (ö. 1826) tarafindan verilmiştir. O, matbaada basılan kitapların saygisızca muamele gördüğüne ve meyvelerle birlikte yan yana dükkânlarda satıldığına şahit olmuştur. Bu durumun kitapları aşağılamak anlamına geldiğini belirten Fleckles, matbaada basılan metinlerin elle yazılan kitaplar gibi kutsal olduğunu dile getirmektedir. Onun da asıl rahatsız olduğu husus, Yahudi dinî metinlerinin Yahudi olmayan matbaacılar tarafindan basılmasıdır. Bulunduğu şehirde matbaacılık yapan kişinin Yahudi olmadığını belirten müellif, Yahudi dinî kurulu olarak kendisine bu kitapları dükkânlara satmamasını ifade eden bir uyarıda bulunduklarını, fakat Hıristiyan olan bu matbaacının devlet nezdinde kendilerinden daha imtiyazlı ve

48 Yair Hayim Baharah, Havot Yair, Mahon Eked Sfarim, Ramat Gan 1997, c. 2, fetva no: 184; Freehof, a.g.e., s. 231.

49 Baharah, a.g.e., fetva no: 109.

50 Yona ben Eliyahu Landsofer, Bney Yona, Kudüs 2005, siman:271, seif: 25. 
daha güçlü olduğunu, bu sebeple de ona söz geçirmenin imkânsız olduğunu nakletmektedir. ${ }^{51}$ Fleckles, bir başka fetvasında Sefer Toraların ve Tanrı'nın isimlerinin deriye harf sırasına göre yazılması gerektiğini; hâlbuki matbaada bu şartın yerine gelmediğini, bu sebeple de litürji kullanımına uygun olmadığını belirtmektedir. ${ }^{52}$ Burada da Fleckles'in kutsallıkla litürji kullanımı arasında ayrıma gittiği görülmektedir.

\section{b. Matbaa Baskısının Dinen Geçerli Olduğunu Savunanlar}

Matbaada basılan metinlerin kutsallık taşıyıp taşımamasıyla ilgili tartışmalarda olumlu görüş bildiren ve gerek parşömene gerekse kâğıtlara basılan dinî literatüre kutsallı atfedilerek azami hürmetin gösterilmesi gerektiğini ifade eden Yahudi âlimlere de rastlanmaktadır. Örneğin Moses Isserles (ö. 1575), bir metnin kutsal olup olmamasının, içerisinde Tanrı'nın isimlerinin bulunmasına ve oluşturulma niyetine bağlı olduğunu belirterek elle yazılan metinlerle matbaada basılanlar arasında bir fark olmadığını iddia etmektedir. ${ }^{53}$

Konuyla ilgili en çarpıcı örnek, Samuel de Medina'ya (ö. 1589) sorulan bir soruda görülmektedir. Soruyu soran kişi Selanik’teki matbaacıların kitap cildi yaparken müsveddeleri kullanmalarını eleştirmekte ve ciltçilerin dinî metinlere saygısılık yaptığını düşünmektedir. Soru şu şekildedir:

“Selanik'te bir gelenek olarak ciltçiler tefsirler, midraşlar, Tora, Neviim, Ketuvim gibi matbaada basılan kitaplardan artakalan fazlalık kâğıtları kitap cildi yapımında kullanıyorlar. Bu artakalan kâğıtları bir yapıştırıcıyla bir araya getirip tutturarak sert bir tabaka elde ediyorlar. Sonra bu tabakaları kitaplara kapak cildi olarak yapıştırıyorlar. Görüldüğü kadarıyla bu artakalan kâğıtlardaki metinler de yapıştırıcı marifetiyle yok ediliyor. Yaptıkları sadece bununla da sınırlı değil. Onlar bu tabakaları küçük parçalara ayırarak küçük hacimli kitaplar için cilt olarak kullanıyorlar. Küçük tabakalara ayırırken ortaya çıkan küçük parçaları da cilt ile kitabın ebadını tutturmak için kullanıyorlar. Sonrasında da bu kâğıt parçaları atılarak ayakaltında çiğneniyor. İşin hakikati şu ki bu durum halk nezdinde de benim gibi bir cahilin gözünde de şaşılacak bir iş olarak karşımızda duruyor. Ağzımı açacak

51 Eliezer ben David Fleckles, Teşuva me-Ahava, ed. Yisrael Zeev, New York 1966, c. 1, no:9; Marvin J. Heller, Printing the Talmud: Earliest editions, s. 11; Freehof, a.g.e., s. 231.

52 Fleckles, a.g.e., no:391; Freehof, a.g.e., ss. 231-232.

53 Martin Przybilski, a.g.m., s. 105. 
bir durumum yok, zira onlar bu işi yaparken büyük bir otoriteye dayanıyorlar. ${ }^{54}$ Fakat bu durum benim kafamı karıştırdı. Kendimi tutamadım ve gördüklerime inanamadım. Gücüm elverdiği ölçüde bu işin cevazına fetva veren bir otoriteyi bulmaya karar verdim. Zira gördüğüm kadarıyla bu işte apaçık bir yanlışlık var. Ayrıca hiçbir büyük otoritenin böyle bir şeye cevaz vereceğine de inanmıyorum. Onlar bu işi adet edinmişler. Öncelikle başta en azından şunu söylemek uygun olur ki onların bu işin cevazına yönelik dört gerekçe öne sürdükleri görülmektedir. Bu gerekçeler şunlardır: Birincisi; yazının malzemesiyle ilgilidir. Zira bütün kutsal yazılar, kitaplar, tefilin, mezuzalar yazı ile yazılmalı oyma/nakşetme/baskı yoluyla değil. Hatta boşanma belgesinde bile "ve o yazar" olması gerek, baskı ya da nakşetme yoluyla değil. Matbaa basımı asla yazı yerine geçmez, bilakis oymacılık/kazımadır (hakika). İkincisi; metnin şeklî şartlarıyla ilgilidir. Yukarıda zikredilen kutsal metinler kusursuz bir şekilde yazılmış olmalıdır. Nitekim "onları yazdığınızda (Tesniye, 6:9; 11:20)" ifadesinde buna işaret edilmektedir. Matbaa baskısında ise pek çok harf birbirine geçmiş oluyor. Üçüncüsü; üzerine yazılan malzemenin türüyle yani kâğıtla ilgilidir. Zira bütün kutsal yazılar ya parşömene (gavil) ya da papirüse (klaf) veya daha az kaliteli bir parşömen türüne (duchsustos) ${ }^{56}$ yazılmak zorundadır. Açıktır ki bu metinler kâğıt üzerine yazıldığında dinen geçersiz sayılırlar. Dördüncüsü; yazılış amacına yönelik gerekçe olarak isimlendirilebilir. Zikredilen bütün kutsal yazılar özel bir sebebe mebni olarak kaleme alınırlar. Ĕger bir kutsal metin özel olarak bir sebebe mebni yazılmazsa geçersiz kabul edilir. İşte bütün bu gerekçelerden ötürü onlar matbaada bu tür eserleri basmanın ve yaptıkları işin caiz olduğunu düşünüyorlar ve bu şekilde yapmaya devam ediyorlar. Bütün bu gerekçeler onların bu işin cevazı için öne sürdükleri hususlardır. Fakat kanaat-i âcizanem bu gerekçelerden hiçbirisi bu metinlerin genizaya gitmesine gerek olmadan yok edilmesine yönelik iddia için yeterli değildir. Ayrıca o metinleri elle parçalamaya yönelik bir izin de yoktur. Bu tür bir muameleyi biz ancak heretikler tarafindan yazılan kitaplara yapiyoruz. ${ }^{57}$ "

Soruyu soran kişi bu ifadesiyle ciltçilerin bu işin fetvasını büyük bir Yahudi âlimden aldıklarını ima etmektedir. Fakat metinde bu otoritenin kim olduğu belli değildir.

55 Tesniye, 24:1. Bkz. Marcus Jastrow, Dictionary of Targumim, Talmud and Midrashic Literature, 1926, s. 285. Samuel de Medina, Şeelot u-Teşuvot, Lvov 1862, no: 184. Mark Hurvitz, Rabbinic Perception of Prin- 
Samuel de Medina, bu soruya cevap sadedinde dinî açıdan geçersiz olsa bile kutsal yazıların yok edilmemesi ve saklanması gerektiğini belirtmektedir. Matbaacıların kendi elleriyle müsvedde metinleri keserek ve yapıştırıcıyla silerek yok etmelerini şaşkınla karşılayan Medina, bunun büyük bir günah olduğunu belirtmektedir. Bunun kutsal yazılara aleni bir saygısızlık olduğunu ifade eden Medina, matbaacıların ve ciltçilerin parşömen ve deri üzerine değil de kâğıt üzerine yazıldığı için bu metinlerin silinmesinde ya da parçalanmasında sorun olmadığına dair gerekçelerinin de geçersiz olduğunu ifade etmektedir. O, buna örnek olarak Yahudi kaynaklarında Tanrı'nın isminin bir kap kacağın ya da yatağın bacağına yazılı olduğu durumda ne yapılması gerektiğine dair soruların olduğunu, hahamların da bu soruya cevap olarak "Tanrı'nın ismi yazılı kısmın koparılarak saklanması" yönünde fetva verdiklerini nakletmektedir. ${ }^{58}$

Medina konuyla ilgili İbn Meymûn'a sorulan talitin $^{59}$ üzerine Tevrat ayetlerinin yazımı ile ilgili bir sorudan bahsetmektedir. İbn Meymun bu soruya "Bu bid'attir ve milletimizde daha önce böyle bir uygulama olduğunu bilmiyoruz"60 şeklinde cevap vermektedir. ${ }^{61}$ İbn Meymun, iki gerekçeden ötürü talitlerin üzerine Tevrat ayetlerinin yazılmasına karşı çıkmaktadır. Birincisi; Tevrat ayetleri peş peşe sadece mürekkeple Sefer Toralarda yazılabilir, diğer yerlerde yazılamaz. Talitin üzerine yazı yazanlar da bu eylemin yazı değil nakış olduğunu iddia ederek bundan cevaz almaktadırlar. İbn Meymun burada Misır'da yaygın olan bir uygulamadan bahsetmektedir. Buna göre gümüş ve altın plakalara darlık ve sıkıntı zamanlarında münacaat maksatlı okunan 91. Mezmur'un baskısı yapılarak çocukların koluna asılmaktadır. İbn Meymun da bunun doğru olmadığını ifade ederek bu uygulamayı protesto etmiştir. İbn Meymun'un bu yasak için ikinci gerekçesi de Tevrat'ın aşağılanması ve ona saygısızca davranılmasıdır. Zira dua şalıyla insanlar banyo-tuvalete gidiyorlar, yatakta nevresim olarak kullanıyorlar, cinsel ilişki sırasında üstlerine örtüyorlar. Yüce Tanrı'nın ağzından çıkan sözlerin bu tür mekânlarda ve eylemlerde malzeme olması kutsala saygısızlıktır. Ona göre Tanrı'nın isminin geçtiği kısımlar kesilerek saklanmalıdır. ${ }^{62}$ Samuel de Medina, İbn Meymun'dan bu

ting as Depicted in Haskamot and Responsa, Hebrew Union College, Yayımlanmamış Yüksek Lisans Tezi, Cincinnati 1978, ss. 51-55.

58 Medina, a.g.e., no: 184; Hurvitz, a.g.e., ss. 56-59.

59 Yahudilikte dua şalı.

60 Hâzâ eydan bid'atun lem tetekaddem fi'l-milleti fi 'ilmina.

61 İbn Meymûn, Teşuvot ha-Rambam, ed. Blau, c. 2, ss. 511-513.

62 İbn Meymûn, Teşuvot ha-Rambam, ed. Blau, c. 2, ss. 511-513.

Belleten, Ağustos 2020, Cilt: 84/Sayı: 300; 559-584 
fetvayı aktararak matbaacıların kutsal yazıları kesip yapıştırıcıyla yazıları kaybetmelerinin büyük bir günah olduğunu ifade etmektedir. ${ }^{63}$

Matbaada basılan get belgesi yazılmış olarak kabul edilir mi ve dinen geçerli midir? Bu soru, Menahem Azarya de Fano'ya (ö. 1620) sorulmuştur. Fano, mürekkeple kâğıt üzerine baskı aletiyle bastırılarak ortaya çıkarılan boşanma belgelerinin geçerli olduğunu ifade etmektedir. Kendinden önce matbaada basılan boşanma belgesini, matbaa baskısını "yazı" değil "baskı" kabul edip geçersiz sayanlar olduğunu hatırlatan Fano, kendisinin matbaa işinde mahir olduğunu, kendi matbaasında birçok işçi kiraladığını ve onları denetlediğini belirtmektedir. Ona göre, söz konusu iddiaların ne Yahudi hukuku açısından ne de matbaacılık faaliyeti açısından bir gerçeklik payı yoktur. Harfler kâğıda mürekkepsiz bir biçimde nakşedilmiş olsa bile okunabiliyorsa o metin boşanma belgesi olarak geçerlidir. Baskılarını mürekkeple yaptığına dikkat çeken Fano, kâğıt üzerinde yapılan şeyin oymacılık (hakak) değil, baskı (defus) işi olduğunu vurgulamaktadır. Fano, matbaacıların baskıda harflerin tam bir şekilde mürekkeple çıkmasını sağladıklarını aktarmaktadır. ${ }^{64}$

Fano, Talmud'da hahamların, boşanma belgesi için kullanılan katav fiilinden ötürü "katav (yazı) olacak, hakak (oymacılık/kazıma) olmaz"65 dediklerini aktarmaktadır. Matbaadaki baskıcılık faaliyetinin yazı fiilini karşıladığıyla ilgili Fano’nun getirdiği delillerden birisi de Hz. Musa'ya verilen taş tabletlerdir. Tevrat'ta bu tabletlerin üzerindeki yazılar için Çıkış 34:1 ve 32:16'da katavti (yazacağım) ve ktiv harut (kazınmış/oyulmuş yazılmış) ifadeleri geçmektedir. Fano, bunu yazma fiiline örnek olarak kullanmaktadır. Bir diğer ifadeyle yazmak fili, bir insanın eline kalem alarak yaptığı eylemle sınırlı olmamaktadır. Ona göre harflerin kenarlarını yontarak harfi öne çıkarmak suretiyle de harfin kendisini oyup kenarları ortaya çıkarmak suretiyle de bu işlem geçerli olur. O, buna Kudüs Talmudu'ndan delil getirmektedir. Buna göre bir kâtip bir derinin üzerini harfler oluşturacak şekilde yırtarak bir metin yazarsa bu boşanma belgesi geçerli olur, suret şeklinde yaparsa geçerli olmaz. ${ }^{66}$ Bu durumun matbaada basılan boşanma belgeleri için de geçerli olduğunu belirten Fano, matbaada oymacılık ya da kakmacılık şeklinde bir boşanma belgesi verilmediğini, oyma ya da kakma yapılmış harflerden oluşan bir tabakadan baskı

63 Medina, a.g.e., fetva no: 184; Hurvitz, a.g.e., ss. 59-61; Freehof, a.g.e., ss. 230-231.

64 Menahem Azarya de Fano, Şeelot u-Teşuvot, Defus Solomon, Kudüs 1963, fetva no: 93; Hurvitz, a.g.e., ss. $65-67$.

65 Babil Talmudu, Gittin, 20a.

66 Babil Talmudu, Gittin, 44b. 
işi yapılarak mürekkeple kâğıt üzerine metnin basıldığına dikkat çekmektedir. ${ }^{67}$

Konuyla ilgili bir diğer soru da Benyamin Slonik'e (ö. 1619) sorulmuştur. Soru iki farklı yön içermektedir. İlk kısımda matbaada basılan eserlerin tüy kalemle deri üzerine yazılan kitaplara kıyasla kutsallıklarının olup olmadığı, devamında ise matbaada kullanılan ve üzerinde Tanrı'nın ismi yazılan kâğıtların müsvedde olarak kullanılıp kesilerek cilt yapımında kullanılmalarının caiz olup olmadığı sorulmaktadır. Slonik, elle yazılan kutsal yazıların tamamının matbaada basıldığında da kutsal olduğunu belirtmektedir. On Emir’in yer aldığı oyma yoluyla metni oluşturulan tabletler için de yazı (katav) ifadesinin kullanıldığını belirten Slonik, matbaa basımında ne oyma ne de kakmacılı̆̆ın söz konusu olduğunu ifade etmektedir. Slonik, baskı faaliyetinde kâğıtla temas eden şeyin mürekkep olduğunu, kâğıt üzerinde oyma ya da kakma yoluyla değil tabakalarda hazırlanan harflerin mürekkeplerinin kâğıda basılması yoluyla metin elde edildiğini dile getirmektedir. Bu sebeple de matbaada basılan metinler yazı yazmak fiiliyle kastedilen şartı tam olarak yerine getirmektedir. ${ }^{68}$

Slonik, matbaa baskısına yönelik eleştirilerden birinin de kutsal metinlerin niyet edilerek harf harf kelime kelime yazılması ve her bir harfte ona hak ettiği saygınlığın gösterilerek metnin tamamlanmasıyla ilgili olduğunu aktarmaktadır. Bu iddiaya göre matbaada sayfa aynı anda basılmaktadır ve içerisinde gerek Tanrı'nın kutsal ismi gerek diğer kutsal metin parçalarıyla ilgili hassasiyet gözetilmemektedir. Matbaa baskısının kutsallığını sorgulayanların bir diğer itirazları da buradan gelmektedir. Slonik, buna itiraz sadedinde Talmud'da Ben Kamtsar isimli Tevrat kâtibinden bahsetmektedir. ${ }^{69}$ Yukarıda da ifade edildiği üzere Ben Kamtsar, parmaklarının arasına dört adet tüy kalemi alarak Y-h-v-h harflerinden oluşan özel ismi (Yahve) tek seferde yazabilmesine rağmen bunun tekniğini kimseye öğretmemiştir. Bu sebeple de hahamlar onun hakkında "ismi yok olsun" şeklinde beddua etmişlerdir. Slonik, Talmud'daki bu rivayete dayanarak Tanrı'nın özel ismini tek parçada yazmanın Talmud hahamları tarafindan çok büyük bir marifet ve değerli bir şey olarak görüldüğünü öne sürmektedir. Bu örneği matbaayla ilişkilendiren Slonik, bu açıdan bakıldığında matbaa baskısının daha faydalı ve daha kutsal olarak bile mütalaa edilebileceğini dile getirmektedir. Tevrat yazılırken kâtibin, Tanrı'nın isminin geçtiği yerleri telaffuz ederek yazması gerektiğini belirten Slonik,

67 Fano, a.g.e., fetva no: 93; Hurvitz, a.g.e., ss. 67-68.

68 Benyamin Slonik, Mas'at Benyamin, Kudüs 1980, fetva no: 99; Hurvitz, a.g.e., ss. 72-75.

69 Babil Talmudu, Yoma, 38b. 
matbaa basımı sırasında bir sayfada kaç kere geçiyorsa o sayfayı basan matbaacının tek bir telaffuzla bu sorumluluğunu yerine getirmesinin mümkün olduğunu ifade etmektedir. ${ }^{70}$

Diğer sorun da müsvedde kâğıtların kesilerek cilt yapımında kullanılmalarına dairdir. Slonik, kendi tecrübelerinden hareketle matbaacıların metinlerin dışında kalan kâğıtların köşelerindeki boşlukları keserek cilt yaptıklarını düşünmektedir. Kâğıdın boş kısımlarının kutsal metinden bir parça olarak kabul edilmeyeceğini belirten Slonik, sadece metnin olduğu kısmin kutsal olduğunu ifade etmektedir. Slonik metnin silindiği ve Tevrat metninin kaybolduğu durumlarda Sefer Tora ile irtibatı kalmadığı gerekçesiyle köşedeki boşlukları muhafaza etmeye gerek olmadığını vurgulamaktadır. Diğer türlü bir Sefer Tora tek parça halinde duruyor ve yazılar da üstündeyse o zaman onunla birlikte kenardaki boşluk da muhafaza edilmeyi hak eder. O, ayrıca Mişna'da ${ }^{71}$ Sefer Toranın alt ve üst boşluklarının da kutsal metin muamelesi gördüğünü aktarmaktadır. Tevrat tomarının yazılması için gereken kurallardan birisi de üst ve alttan ayrılacak boşlukların miktarıyla ilgilidir. Slonik, bu miktar içerisinde kalan boşlukların Sefer Tora çerçevesinde işlem göreceğini, bundan fazla boşluk ayrılmışsa kural miktarının dışındaki kısımların kutsal kabul edilmeyeceğini bildirmektedir. Bu sebeple de ona göre, bu kısımların kesilmesinde ve kullanılmasinda herhangi bir mahzur yoktur. ${ }^{72}$

Matbaa baskılarını destekleyen bir diğer Yahudi âlim de David Halevi Segal'dir (ö. 1667). O, matbaa baskısı metinlerde kutsallık olmadığına dair sözler duyduğunu fakat matbaa baskısı metinlerin elle yazılanlar gibi kutsallık içerdiğini vurgulamaktadır. O, matbaada yapılan faaliyetin baskı olduğunu ve oymacılık-kakmacılık olarak isimlendirilemeyeceğini, bu sebeple tam olarak yazı ifadesini karşıladığını belirtmektedir. Bununla birlikte o, boşanma belgelerinin elde yazılması gerektiğini belirterek matbaada basılmasına ihtiyatla yaklaşmaktadır. Ona göre matbaa baskısı her halükarda biraz oymacılığı andırmaktadır. ${ }^{73}$

Yehiel Michel Epstein (ö. 1908), Aruh ha-Şulhan isimli eserinde matbaada basılan eserlerin kutsallıklarıyla ilgili değerlendirmede bulunmaktadır. O, kendisinden önce bazı Yahudi âlimlerin matbaa baskısının el yazmasının yerini tutmayacağını

70 Slonik, a.g.e., fetva no: 99; Hurvitz, a.g.e., ss. 75-82.

71 Mişna, Yadayim, 3:4.

72 Slonik, a.g.e., fetva no: 100; Hurvitz, a.g.e., ss. 82-95; Freehof, a.g.e., s. 231.

73 David Halevi Segal, Turey Zahav al Şulhan Aruh, Yore Dea, fetva no 271, seif: 8. Jacobs, a.g.e., s. 154. 
söylediğini ancak birçoğunun da yerini tutacağını bildirdiklerini aktarmaktadır. Epstein, kendi gözlemleri istikametinde matbaadaki baskı faaliyetlerini şu şekilde aktarmaktadır:

"Matbaa baskllarında önce harfleri diziyorlar, sonra da harflere siyah mürekkep sürüyorlar. Ardından da yerleştirdikleri kâğgdın üzerine tek bir çırpıda baskıyı yapıp harfleri kâğıdın üzerine baskilıyorlar. Eğer mürekkepli harfleri derinin üzerine bassalar ya da deriyi harflerin üzerine bassalar bu yazı olabilirdi. Ayrıca matbaada kullandıkları mürekkep sıradan bir mürekkep. Hâlbuki âlimlerimiz kutsal metinlerin yazımında kullanılacak mürekkebin siyah kaşer bir mürekkep olmasını şart koşmuşlardır. Bu durumda kâğıdı mürekkepli harflere basmak, bildiğimiz anlamda yazı değildir. Ayrıca bu işlem sırasında makine kendisi adam kullanmadan kâğıdı çevirerek harflere yapıştırıyor, bu elbette yazı işlemi değildir. Hâlbuki yazı ifadesi, bir kişinin iradi bir şekilde yazdığı metin için kullanılır, yoksa kendi kendine bir alet ile ortaya çıkarılan bir metin için kullanılmaz. Ayrıca matbaa baskısında yazım işinde olduğu gibi hiçbir kutsallık niyeti bulunmamaktadır. Bununla birlikte matbaada basılan Tevratlar kutsallık içermektedir. Fakat elle deriye yazılan Sefer Toralar seviyesinde değildir. Fakat bir şekilde matbaa baskısı kitaplarda da kutsallık mevcuttur. Bu sebeple de matbaa baskısı kitapları yakmak ve bu kitaplara saygisizca davranmak yasaktır, bu konuda en ufak bir şüphe yoktur. ${ }^{74}$ "

Görüldüğü üzere matbaanın icadından bugüne kadar Yahudi âlimler, Tevrat'ın matbaada basılması konusunda farklı şekillerde tutum almışlardır. Bazı âlimler doğrudan matbaa işiyle ilgilendikleri için daha teknik bilgilerle değerlendirmelerde bulunarak matbaa baskılarının dinen caiz olduğunu dile getirmişlerdir. Matbaa baskılarıyla ilgili paylaştığımız bu fetvaların günümüzde de farklı formlarıyla modern gelişmeler ışı̆̆ında devam ettiğine şahit olmaktayız. Günümüz itibariyle bu tür tartışmalar, serigrafi baskısıyla oluşturulan Tevratlar için de geçerlidir.

\section{Sonuç}

Yahudi geleneğinin matbaanın icadıyla ilgili tutum ve değerlendirmelerini incelediğimiz bu çalışmamızda ana hatlarıyla şu sonuçlara ulaşılmıştır:

I. Yahudi dinî literatüründe matbaanın icadıyla ilgili olumsuz bir ifade olmadığı görülmektedir. Bilakis matbaanın icadından hemen sonra basılan İbranice kitap-

74 Yehiel Michel Epstein, Aruh ha-Şulhan (Yore Dea), Kudüs 1987, c. 2, fetva no: 27 1, seif: 39.

Belleten, Ağustos 2020, Cilt: 84/Sayı: 300; 559-584 
larda matbaa için "kutsal zanaat" gibi ifadelere yer verilmiş ve matbaanın icadı sevinçle karşılanmıştır. Bunun temel sebebi de matbaanın Tevrat'ın ve Tanrı'nın adının/öğretilerinin daha çok kişiye ve daha fazla coğrafyaya ulaşmasına hizmet etmesidir.

II. Matbaanın çok faydalı bir icat olduğu görüldüğu için bazı Yahudi âlimler bu kadar yararlı bir icadın bir Hıristiyan tarafından değil, Yahudiler tarafindan icat edilmesi gerektiğini söyleyerek matbaaya Yahudi köken bulma arayışına girmişlerdir. Bu çerçevede Musa, Eyüp, Süleyman ve Mişna âlimleri döneminde matbaanın bilindiği iddiası ortaya atılmıştır.

III. Matbaayla ilgili temel tartı̧ma Sefer Tora, tefilin, mezuza ve get yazımlarına yöneliktir. Bu da bu objelerin yazmak filiyle ifade edilen bir ameliyeyle ortaya çıkarılmasından kaynaklanan bir sorundur. Yahudi âlimler matbaadaki baskı faaliyetinin bir yazım mı yoksa oymacılık-kakmacılık mı veya başka bir şey mi olduğu konularında ihtilafa düşmüşlerdir. Bununla birlikte kahir ekseriyeti matbaadaki baskıyı yazı yazmak fiili çerçevesinde değerlendirmişlerdir.

IV. Bazı Yahudi âlimler, metnin kutsal olup olmamasıyla sinagogda litürjide kullanılıp kullanılması konusunu ayrı çerçevelerde değerlendirmiştir. Bu noktada matbaada basılan eserlerin ister kâğıda ister parşömene basılsın her halükarda kutsallığı vurgulanmıştır. Fakat deri parçalarına basılarak sonrasında dikilip rulo haline getirilse de bu tür Tevratların sinagogda Tevrat okuma ritüelinde okunmasina genel olarak olumsuz bakılmaktadır. Nitekim günümüzde de her türlü kolaylığa rağmen Yahudi geleneğinde Tevrat kâtipleri (soferim) var olmaya devam etmekte ve dünyanın her yerindeki sinagoglarda kâtipler tarafindan elle deri üzerine yazılan Sefer Tora adı verilen rulo şeklindeki Tevratlar kullanılmaktadır. 


\section{KAYNAKLAR}

Amram, David Werner, The Makers of Hebrew Books in Italy, Edvard Stern Publishing Philadephia 1909.

Amram, Daniel Chwolson, Reşit Maase ha-Defus be-Yisrael, Warsaw 1897.

Baharah, Yair Hayim, Havot Yair, Mahon Eked Sfarim, Ramat Gan 1997.

Beit-Arie, Malachi, "The Relationship between Early Hebrew Printing and Handwritten Books: Attachment or Detachment", Library Archives, and Information Studies, ed. Dov Schidorsky, Magnes Press, Kudüs 1989, ss. 1-26.

Berliner, Avraham, Ktavim Nivharim, Mosad Rav Kook, Kudüs 1945.

Bleich, J. David, "Survey of Recent Halakhic Periodical Literature: Silk Screened Torah Scrolls", Tradition: A Journal of Orthodox Jewish Thought 37:1 (2003), ss. 79-92.

Chajes, Zvi Hirsch, Şeelot u-Teşuvot, Zolkiew 1850.

Eliot, Simon ve Jonathan Rose, A Companion to the History of the Book, Wiley-Blacwell Publishing, Hong Kong 2009.

Epstein, Yehiel Michel, Aruh ha-Şulhan (Yore Dea), Hanoh Wagşal Publishing, Kudüs 1987.

Fano, Menahem Azarya de, Şeelot u-Teşuvot, Defus Solomon, Kudüs 1963.

Fleckles, Eliezer ben David, Teşuva me-Ahava, ed. Yisrael Zeev, Chaim Gross Publishing, New York 1966.

Freehof, Solomon B., The Responsa Literature, Varda Books, Illinois 2001.

Gans, David, Tsemah David, ed. Mordechai Breuer, Magnes Press, Kudüs 1983.

Gracia, Manule Jose Pedrasa, "Minor Printing Offices in Fifteenth and Sixteenth Centuries", Print Culture and Peripheries in Early Modern Europe, ed. Benito Rial Costas, Brill, Leiden 2013.

Gumbiner, Avraham, Magen Avraham (Oreh Hayim), https://www.sefaria.org/Magen_Avraham.32.47 ?lang=he\&with $=$ Machatzit $\% 20$ HaShekel\&lang2 $=$ he (Erişim Tarihi: 25.08.2019).

Hacker, Joseph R. ve Adam Shear, The Hebrew Book in Early Modern Italy, University of Pennyslvania Press, Philadelphia 2011. 
Heller, Marvin J., Printing the Talmud: A History of the Earliest Printed Editions of the Talmud, Brill, Leiden 1992.

Heller, Marvin J., The Seventeenth Century Hebrew Book, Brill, Leiden 2011.

Hirsch, Rudolf, Printing, Selling and Reading 1450-1550, Harrassovvitz, Wiesbaden 1967.

Horovitz, Şabtay ben Akiva, Şefa Tel, Hanau 1612.

Hurvitz, Mark, Rabbinic Perception of Printing as Depicted in Haskamot and Responsa, Yayımlanmamış Yüksek Lisans Tezi, Hebrew Union College, Cincinnati 1978.

İbn Meymûn, Musa, Teşuvot ha-Rambam, ed. Jehoshua Blau, Mekitsey Nirdamim, Kudüs 1989.

Jacobs, Louis, A Tree of Life Diversity, Flexibility, and Creativity in Fewish Law, The Littman Library of Jewish Civilization, Oregon 2007.

Jastrow, Marcus, Dictionary of Targumim, Talmud and Midrashic Literature, Luzac \& Co., London 1903.

Kahana, Yitshak Zeev, Mehkarim be-Sifrut ha-Teşuvot, Mosad Rav Kook, Kudüs 1973.

Katzenellenbogen, Hezekiel, Knesset Yehezkiel, Hotsaat Yisrael Zeev, Sudilkov 1732.

Landsofer, Yona ben Eliyahu, Bney Yona, Kudüs 2005.

Mann, Vivian B. ve Daniel D. Chazin, "Printing, Patronage and Prayer: Art Historical Issues in Three Responsa". Images: A Journal of Jewish Art and Visual Culture 1 (2007), ss. 92-94.

Medina, Samuel de, Şeelot u-Teşuvot, Lvov 1862.

Mehlman, Israel, Genuzot Sefarim, The Jewish National and University Library Press, Kudüs 1976.

Meral, Yasin, İstanbul'da Yahudi Matbuat, Divan Kitap, İstanbul 2016.

Mongan, Elizabeth ve Edwin Wolf, The First Printers and Their Books, The Free Library of Philadelphia, Philadelphia 1940.

Offenberg, Adri K., Hebrew Incunabula in Public Collections, De Graaf, Nieuwkoo 1990. 
Pollak, Michael, "The Invention of Printing in Hebrew Lore", Gutenberg-Fahrbuch (1977), ss. 22-28.

Portaleone, Avraham, Şiltey Giborim, Mantua 1607.

Provençal, Moşe, Şeelot u-Teşuvot, ed. Avraham Yosef Yanay, Mahon Or ha-Mizrah, Kudüs 1989.

Przybilski, Martin, "Jewish Concepts of Holiness of Script in the Age of Printing: The Case of Genizah", The Aura of the Word in the Early Age of Print. ed. Jessica Biskirk ve Samuel Mareel, Routledge Publishing, Oxon 2016.

Rakover, Nahum, Zhut ha-Yotsrim ba-Mekorot ha-Yehudim, Jewish Legal Heritage Society, Kudüs 1991.

Richardson, Brian, "The Debates on Printing in Renaissance Italy", La Bibliofilia 100:2/3 (1998), ss. 138-142.

Ruderman, David B., Ferwish Thought and Scientific Discovery in Early Modern Europe, Yale University Press, New Haven 1995.

Schaeper, Silke, "Inventory of Hebrew Incunabula", Catalogue of Books Printed in the Fifteenth Century Now in the Bodleian Library, ed. Alan Coates, Oxford University Press, Oxford 2005.

Segal, David Halevi, Turey Zahav al Şulhan Aruh, (Yore Dea), https://www.sefaria. org/Turei_Zahav_on_Shulchan_Arukh\%2C_Yoreh_De'ah.271?lang=bi (Erişim Tarihi: 25.08.2019).

Sirat, Coletta, Hebrew Manuscripts of the Middle Ages, trans. Nicolas de Lange, The Press Syndicate of the University of Cambridge, Cambridge 2002.

Sladek, Pavel, "The Printed Book in the 15th and 16th Century Jewish Culture", Hebrew Printing in Bohemia and Moravia, ed. Olga Sixtova, Academia and the Jewish Museum in Prague, Prague 2012.

Slonik, Benyamin, Mas'at Benyamin, Kudüs 1980.

Yaari, Avraham, Mehkarey Sefer, Mosad Rav Kook, Kudüs 1958. 